\title{
Motivation and Satisfaction of Employees in the Workplace
}

\author{
Maja Rožman, Sonja Treven, Vesna Čančer
}

Faculty of Economics and Business, University of Maribor, Maribor, Slovenia

\section{Abstract}

Background: The aging of the European population is a demographic trend reflected in the ever-growing number of older employees. This paper introduces the importance of motivation and satisfaction in the workplace among age diverse employees in Slovenian companies. Objectives: The goal is to investigate the differences between the motivation and satisfaction of employees from different age groups in the workplace. Methods/Approach: The paper is based on research including a survey of two age groups of employees in Slovenia. We employed the Mann-Whitney $U$ test to verify differences in the motivation and satisfaction in the workplace between the two groups. Results: Older employees are more motivated by flexibility in the workplace; autonomy at work; good interpersonal relationships in the workplace; the possibility of working at their own pace; respect among employees; equal treatment of employees regardless of their age. They are more satisfied with interpersonal relationships in the company; their work; working hours and the distribution of work obligations; and facilitation of the self-regulation of the speed of work performed. Conclusions: Motivation and satisfaction change as individuals age. Using this information, managers and employers can apply appropriate measures to contribute to employees' well-being and better workplace performance, better working relationships with colleagues, higher productivity, and greater creativity.

Keywords: motivation; satisfaction; employees; human resource management JEL classification: J24

Paper type: Research article

Received: May 13, 2016

Accepted: Mar 11, 2017

Citation: Rožman, B., Treven, S., Čančer, V. (2017), "Motivation and Satisfaction of Employees in the Workplace", Business Systems Research, Vol. 8, No. 2, pp. 14-25. DOI: 10.1515/bsrj-2017-0013

\section{Introduction}

Due to demographic changes in society, which present various challenges in the management of human resources, the percentage of employees older than 50 years is increasing. This results in the changes in frequency and size of age diversity in companies (Baltes et al., 2011).

On the other hand, Hertel et al. (2013) suggested that age diverse workers have different experience and background; age diversity of workers in companies could 
increase creativity, innovation, and problem solving. Diversity in role expectations, working styles, and general values causes various needs for communication, coordination and conflict management. Wiley (1997) argued that employers must understand what motivates employees; they must also emphasize employees' satisfaction. This is essential to improve productivity and ensure companies success (UK Essays, 2015). Furthermore, Lange et al. (2006) asserted that aging influences biological, psychological and social functions over time, thereby affecting each individual's organizational, societal and personal levels. This also means that employees' age diversity has different effects on work-related attitudes.

The research of Kooij et al. (2011) clearly showed a significant negative relationship between age and growth-related motives, and positive relationship between age and positive affect at work, and between age and personal needs and job characteristics. Organizations should therefore emphasize the management of human resources and age diversity.

This article presents the importance of human resource management in the context of motivation and satisfaction of older and younger employees. The goal is to investigate the differences between the motivation and satisfaction of employees from different age groups in the workplace. In the article, we answered the following research questions: RQ1: Are there statistically significant differences in motivation in the workplace between older and younger employees? RQ2: Are there statistically significant differences in job satisfaction in the workplace between older and younger employees? This research presents descriptive statistics and a MannWhitney test for answers about motivation and satisfaction between two groups of employees in companies in Slovenia. Based on our results, we found differences in motivation and satisfaction between younger and older employees.

The article presents a review of the literature on employees' motivation and satisfaction, a description of methodology, results about the motivation and satisfaction of younger and older employees, and finally a discussion of the findings.

\section{Literature review}

\section{Motivation in the workplace}

In order to compete effectively in the global marketplace, companies should design jobs so that stress can be reduced, and the motivation and satisfaction of employees and their performance can be increased (Garg and Rastogi, 2006).

According to Bartol and Martin (1998), motivation "energizes behavior, gives direction to behavior, and underscores the tendency to persist". Islam and Ismail (2008) suggested that motivation is an important aspect by leading function in influence on others to work toward companies' goals.

The motivation of older employees to work and remain active in the workplace has been examined in a few studies. Empirical research has often focused on young employees (Kooij et al., 2008). Stamov-Roßnagel and Biemann (2012) explained that the stereotypical beliefs of older employees having a lower ability, less productivity, and less motivation at work reduce work-friendly environments for older workers. Such a working environment puts motivation on the line. Further, authors StamovRoßnagel and Biemann (2012) argued that it is crucial to understand age-related changes in work motivation. According to Stamov-Roßnagel and Hertel (2010), maintaining a high level of motivation at different ages, and for older workers in particular, is a prerequisite for successful management when dealing with changes in work capabilities. 


\section{Satisfaction in the workplace}

Today's companies operate in a competitive environment at a global level and are forced to do everything on the market to become and remain competitive. In view of such a situation, it is crucial that management takes care of employee satisfaction, which is a key factor for organizational effectiveness and efficiency and for the successful implementation of the corporate strategy (Bigliardi et al., 2012).

According to Jex and Britt (2008), satisfaction in the workplace is crucial for organizational success. Jex and Britt (2008) also argued that satisfied employees commit to work more and have higher rates in retention and productivity. The authors also assert that high satisfaction often means lower level of absenteeism while improving mental and physical health. Harrison et al. (2006) argued that workplace satisfaction can also be linked to other key factors of employees in the context of workload, stress and supervision at work, and the balance in domestic activities and work enviroment.

However, Goetz (2001 in Aghazadeh, 2004) concluded that poorly managed diversity can have long-term effects on employee productivity and satisfaction; employees who view themselves as more respected also work harder and are more innovative and involved in work environment.

On the other hand, some employees, due to the existence of stereotypes and prejudices, feel less important for the organization; therefore, their working capacity is reduced. Poor management of diversity can have negative consequences: the reduction of skills, motivation and employee satisfaction, which means less efficiency. If company does not take into account the existence and importance of the diversity of the workforce, it may come to situation that the company and the employees will not achieve their goals or exploit their potential (Aghazadeh, 2004).

Therefore, Aghazadeh (2004) emphasized the importance of human resources and their role considering proper management of age diversity in the organization. Thus, according to Lawrence (2001 in Aghazadeh, 2004), in today's competitive environment, diversity is the norm of successful organizations

\section{Methodology}

\section{Sample and data}

The motivation and satisfaction in the workplace between different age groups of employees were examined in the empirical study based on a quantitative method of data gathering. We sent 525 questionnaires to both private and public, randomly selected companies in Slovenia in January 2016. According to business activity, the survey included capital goods, basic industries, consumer services, consumer nondurables, consumer durables, healthcare, finance, public utilities, transportation, and technology. Small, medium sized and large companies participated in this survey. The response rate was $76 \%$. The research includes 400 companies and one employee in each company. The employees were divided into two groups: younger employees were classified into the group of under 50 years of age, and older employees were classified into the group from 50 to 65 years of age. Definitions of older employees vary in the literature. Mostly, the lower age limit defining older employees are 45 years (Brooke, 2003) or 50 years (Ilmarinen, 2001). Ghosheh et al. (2006) argued that the term "older employees" includes workers between 40 and 50 years of age. As there are different theoretical principles, we decided to use 50 years old as the boundary for our research. Our sample consists of 400 employees; 174 young employees and 226 older employees answered the questionnaires. Table 1 
shows the profile of respondents of Slovenia and control variables. The distribution is representative for Slovenia.

Table 1

Profile of Respondents and Control Variables

\begin{tabular}{|c|c|c|c|}
\hline \multicolumn{2}{|c|}{ Characteristic of respondents } & $\begin{array}{l}\text { Number of } \\
\text { respondents }\end{array}$ & Percentage \\
\hline & 18 to 49 years & 174 & $43.5 \%$ \\
\hline Age & 50 to 65 years & 226 & $56.5 \%$ \\
\hline \multirow{5}{*}{$\begin{array}{l}\text { Level of } \\
\text { achieved } \\
\text { education }\end{array}$} & Primary school & 2 & $0.5 \%$ \\
\hline & $\begin{array}{l}\text { Vocational or } \\
\text { secondary school }\end{array}$ & 64 & $16 \%$ \\
\hline & High school & 137 & $34.3 \%$ \\
\hline & University education & 180 & $45 \%$ \\
\hline & $\begin{array}{c}\text { Master's degree or } \\
\text { doctorate }\end{array}$ & 17 & $4.2 \%$ \\
\hline \multirow{12}{*}{$\begin{array}{l}\text { Region where } \\
\text { respondents } \\
\text { performs their } \\
\text { job }\end{array}$} & Pomurje & 45 & $11.3 \%$ \\
\hline & Podravje & 95 & $23.8 \%$ \\
\hline & Koroška & 17 & $4.2 \%$ \\
\hline & Savinjska & 16 & $4 \%$ \\
\hline & Zasavska & 15 & $3.8 \%$ \\
\hline & Posavska & 8 & $2 \%$ \\
\hline & South-east Slovenia & 46 & $11.5 \%$ \\
\hline & Central Slovenia & 120 & $30 \%$ \\
\hline & Gorenjska & 21 & $5.2 \%$ \\
\hline & Primorsko-notranjska & 10 & $2.5 \%$ \\
\hline & Goriška & 3 & $0.7 \%$ \\
\hline & Coastal-Kras & 4 & $1 \%$ \\
\hline \multirow{3}{*}{$\begin{array}{c}\text { Size of } \\
\text { companies of } \\
\text { employees }\end{array}$} & Large company & 102 & $25.5 \%$ \\
\hline & $\begin{array}{l}\text { Medium-sized } \\
\text { company }\end{array}$ & 226 & $56.5 \%$ \\
\hline & Small company & 72 & $18 \%$ \\
\hline
\end{tabular}

Source: Authors' work

Instrument of research

We used various theoretical concepts and research to design the instrument for measuring the motivation and satisfaction of employees in the workplace.

Table 2 shows the research instrument that was developed bysed on several previous researches (Rad and Yarmohammadian, 2006; Monk, 1996; Claes and Heymans, 2008; Shacklock and Brunetto, 2011; Moore, 2007; Gellert and Kuipers, 2008; Peeters and Emmerik, 2008; Stamov-Roßnagel and Biemann, 2012: Kooij et al., 2008; Claes and Heymans, 2008; Templer et al., 2010; Origo and Pagani, 2008; Artz, 2010; Shacklock and Brunetto, 2011; Koc-Menard, 2009; Shacklock and Brunetto, 2011 ; Gellert and Kuipers, 2008; van Dick et al., 2008; Groot and Brink, 1999; Robson et al., 2006; Henkens and Leenders, 2010; Stamov-Roßnagel and Biemann, 2012)

To determine the motivation and satisfaction of employees in the workplace, the employees indicated on a 5-point Likert scale their agreement to the listed statements, where $5=$ completely agree and $1=$ strongly disagree. Likert scale was used for this type of research because we wanted to know the strength of agreement with statements in the questionnaire. 
Table 2

Research instrument

\begin{tabular}{|c|c|c|}
\hline Dimension & Items & Source \\
\hline \multirow{5}{*}{ MOTIVATION } & For better performance at my work it motivates me: & \\
\hline & $\begin{array}{l}\text { ml: Higher salary. } \\
\text { ml3: Good interpersonal relations in the workplace. }\end{array}$ & $\begin{array}{l}\text { Rad and } \\
\text { Yarmohammadian (2006) }\end{array}$ \\
\hline & m2: Compliments from the employer for good work. & Monk (1996) \\
\hline & $\begin{array}{l}\text { m3: The possibility of flexibility in the workplace. } \\
\text { m9: Possibility for training and education. }\end{array}$ & Claes and Heymans (2008) \\
\hline & $\begin{array}{l}\text { m4: The possibility of autonomy at work. } \\
\text { m6: The possibility of working at my own pace. } \\
\text { m7: The possibility of working from home. } \\
\text { m15: The possibility of extended holidays. }\end{array}$ & $\begin{array}{l}\text { Shacklock and Brunetto } \\
\text { (2011); Moore (2007) }\end{array}$ \\
\hline \multirow{12}{*}{ SATISFACTION } & m5: The possibility of diverse work. & Gellert and Kuipers (2008) \\
\hline & m8: The possibility of advancement. & $\begin{array}{l}\text { Peeters and Emmerik } \\
\text { (2008); Stamov-Roßnagel } \\
\text { and Biemann (2012) }\end{array}$ \\
\hline & $\begin{array}{l}\text { m10: The possibility of equal treatment of employees by } \\
\text { age. } \\
\text { m12: Respect between employees. }\end{array}$ & $\begin{array}{l}\text { Kooij et al. (2008); Claes } \\
\text { and Heymans (2008) }\end{array}$ \\
\hline & $\begin{array}{l}\text { m1 1: The possibility of cooperation with other employees } \\
\text { and the allocation of work. } \\
\text { m14: Intergenerational cooperation, thereby reducing } \\
\text { the burden on the workplace. }\end{array}$ & Templer et al. (2010) \\
\hline & At my workplace I am satisfied: & \\
\hline & $\begin{array}{l}\text { s1: With working hours and distribution of work obligations. } \\
\text { s4: With enabled self-regulation of speed of work } \\
\text { performed. }\end{array}$ & Origo and Pagani (2008) \\
\hline & $\begin{array}{l}\text { s2: With flexible working hours. } \\
\text { s5: With the quantity of programs of active aging and } \\
\text { healthy lifestyles. } \\
\text { s8: With flexible work. }\end{array}$ & $\begin{array}{l}\text { Artz (2010); Shacklock and } \\
\text { Brunetto (2011) }\end{array}$ \\
\hline & s3: With the balance between work and private life. & $\begin{array}{l}\text { Koc-Menard (2009); } \\
\text { Shacklock and Brunetto } \\
\text { (2011) }\end{array}$ \\
\hline & $\begin{array}{l}\text { s6: With intergenerational cooperation and, thus, the } \\
\text { distribution of work. }\end{array}$ & $\begin{array}{l}\text { Gellert and Kuipers (2008); } \\
\text { van Dick et al. (2008) }\end{array}$ \\
\hline & $\begin{array}{l}\text { s7: With the working conditions, such as better light, air } \\
\text { conditioning, and bigger inscriptions. } \\
\text { s10: With my work. } \\
\text { s1 1: With the interpersonal relationships in the company. } \\
\text { s12: With the leadership in the company. }\end{array}$ & Groot and Brink (1999) \\
\hline & $\begin{array}{l}\text { s9: With the providing of job-sharing, thereby reducing } \\
\text { the burden on the workplace. }\end{array}$ & $\begin{array}{l}\text { Robson et al. (2006); } \\
\text { Henkens and Leenders } \\
\text { (2010) }\end{array}$ \\
\hline & $\begin{array}{l}\text { s13: With ways of motivating in the company for better } \\
\text { work. }\end{array}$ & $\begin{array}{l}\text { Stamov-Roßnagel and } \\
\text { Biemann (2012) }\end{array}$ \\
\hline
\end{tabular}

Source: Authors' work

\section{Statistical analysis}

Arithmetic means and medians were used for answers considering the motivation and satisfaction of younger and older employees. To verify the normality of the data distribution, Kolmogorov-Smirnov and Shapiro-Wilk tests were used. We found that the data were not normally distributed $(p<0.001)$ for any statement describing the satisfaction and motivation of employees. According to Milenovic (2011), the MannWhitney $U$ test is used to compare two independent groups when the dependent 
variable is either ordinal or continuous, but not normally distributed. Therefore, we verified the differences between younger and older employees with the use of nonparametric Mann-Whitney $U$ test, which is a substitute for the parametric t-test of independent samples.

\section{Results}

In Table 3 we present the medians, means, and results of the Mann-Whitney $U$ test for answers about the motivation of the age groups of employees.

Table 3

Descriptive Statistics and Mann-Whitney Test for Answers about the Motivation of Younger and Older Employees

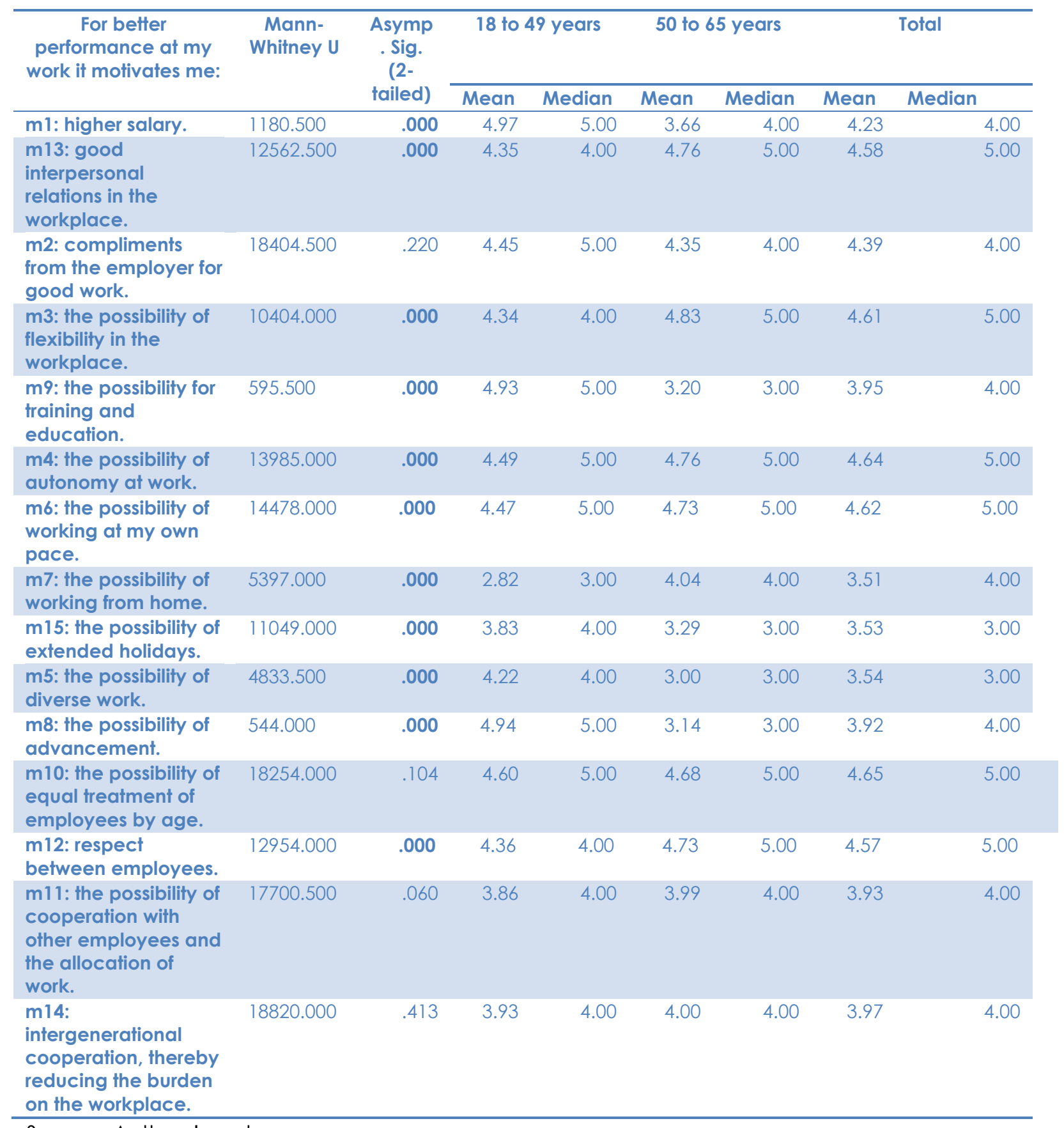

Source: Authors' work 
Table 3 shows the means for answers about the motivation of younger and older employees. The results indicate that, on average, older employees, for better performance at work, highly agree with following motivating factors: the possibility of flexibility in the workplace (Mean: 4.83); the possibility of autonomy at work (Mean: 4.76); good relationships between employees (Mean: 4.76); the possibility of working at their own pace (Mean: 4.73); respect between employees (Mean: 4.73); and the possibility of equal treatment of employees by age (Mean: 4.68). The means for the answers considering these motivating factors are higher for older employees than for younger ones. Younger employees, however, showed the highest agreement on average with the following motivating factors: higher salary (Mean: 4.97); the possibility of advancement (Mean: 4.94); and the possibility for training and education (Mean: 4.93). In these cases, the values of the observed measures of central tendency are higher for younger employees than for older ones. The results of the Mann-Whitney $U$ test (Table 3) showed that the observed differences were statistically significant in most (i.e., 73.3\%) statements. Table 4 presents the medians, means and results of the Mann-Whitney $U$ test for answers about the satisfaction of different age groups of employees.

Table 4

Descriptive Statistics and Mann-Whitney Test for Answers about the Satisfaction of Younger and Older Employees

\begin{tabular}{|c|c|c|c|c|c|c|c|c|}
\hline \multirow{2}{*}{$\begin{array}{l}\text { At my workplace I am } \\
\text { satisfied: }\end{array}$} & \multirow{2}{*}{$\begin{array}{c}\text { Mann- } \\
\text { Whitney U }\end{array}$} & \multirow{2}{*}{$\begin{array}{l}\text { Asymp. Sig. } \\
\text { (2-tailed) }\end{array}$} & \multicolumn{2}{|c|}{18 to 49 years } & \multicolumn{2}{|c|}{50 to 65 years } & \multicolumn{2}{|c|}{ Total } \\
\hline & & & Mean & Median & Mean & Median & Mean & Median \\
\hline $\begin{array}{l}\text { s1: With working hours } \\
\text { and distribution of work } \\
\text { obligations. }\end{array}$ & 19220.500 & .652 & 3.74 & 4.00 & 3.72 & 4.00 & 3.73 & 4.00 \\
\hline $\begin{array}{l}\text { s4: With enabled self- } \\
\text { regulation of speed of } \\
\text { work performed. }\end{array}$ & 16665.000 & .002 & 3.90 & 4.00 & 3.67 & 4.00 & 3.77 & 4.00 \\
\hline $\begin{array}{l}\text { s2: With flexible working } \\
\text { hours. }\end{array}$ & 18396.000 & .165 & 3.26 & 3.00 & 3.29 & 3.00 & 3.28 & 3.00 \\
\hline $\begin{array}{l}\text { s5: With the quantity of } \\
\text { programs of active aging } \\
\text { and healthy lifestyles. }\end{array}$ & 10510.500 & .000 & 3.44 & 3.00 & 2.81 & 3.00 & 3.09 & 3.00 \\
\hline s8: With flexible work. & 19301.500 & .683 & 3.25 & 3.00 & 3.21 & 3.00 & 3.23 & 3.00 \\
\hline $\begin{array}{l}\text { s3: With the balance } \\
\text { between work and } \\
\text { private life. }\end{array}$ & 11885.000 & .000 & 2.62 & 2.00 & 3.13 & 3.00 & 2.91 & 3.00 \\
\hline $\begin{array}{l}\text { s6: With intergenerational } \\
\text { cooperation and thus } \\
\text { distribution of work. }\end{array}$ & 18873.000 & .375 & 3.20 & 3.00 & 3.21 & 3.00 & 3.21 & 3.00 \\
\hline $\begin{array}{l}\text { s7: With the working } \\
\text { conditions, such as better } \\
\text { light, air conditioning, } \\
\text { bigger inscriptions. }\end{array}$ & 14802.500 & .000 & 3.77 & 4.00 & 3.46 & 3.00 & 3.60 & 4.00 \\
\hline s10: With my work. & 18102.000 & .133 & 3.72 & 4.00 & 3.78 & 4.00 & 3.75 & 4.00 \\
\hline $\begin{array}{l}\text { s11: With the interpersonal } \\
\text { relationships in the } \\
\text { company. }\end{array}$ & 15789.000 & .000 & 3.63 & 4.00 & 3.83 & 4.00 & 3.74 & 4.00 \\
\hline $\begin{array}{l}\text { s12: With the leadership in } \\
\text { the company. }\end{array}$ & 17453.500 & .038 & 3.26 & 3.00 & 3.38 & 3.00 & 3.33 & 3.00 \\
\hline $\begin{array}{l}\text { s9: With the providing of } \\
\text { job-sharing, thereby } \\
\text { reducing my burden in } \\
\text { the workplace. }\end{array}$ & 17818.500 & .028 & 3.06 & 3.00 & 3.15 & 3.00 & 3.11 & 3.00 \\
\hline $\begin{array}{l}\text { s13: With ways of } \\
\text { motivating employees in } \\
\text { the company for better } \\
\text { work. }\end{array}$ & 14023.500 & .000 & 2.71 & 3.00 & 3.05 & 3.00 & 2.90 & 3.00 \\
\hline
\end{tabular}

Source: Authors' work 
Table 4 shows that the means for answers about the satisfaction of younger and older employees indicate that, on average, older employees had the highest agreement with: I am satisfied with the interpersonal relationships in the company (Mean: 3.83) and I am satisfied with my work (Mean: 3.78). In the other cases, older employees on average neither agreed nor disagreed. Younger employees showed the highest agreement on average with the following: I am satisfied with facilitating self-regulation of the speed of work performed (Mean: 3.90); I am satisfied with working hours and distribution of work obligations (Mean: 3.74); and I am satisfied with the working conditions, such as better light, air conditioning, and bigger inscriptions (Mean: 3.77).

The results of the Mann-Whitney $U$ test (Table 4) show that the differences are statistically significant in most (i.e. 61.5\%) statements.

\section{Discussion and conclusion}

In this paper we demonstrated that both older and younger employees are motivated and satisfied in the workplace, but in different ways. Based on their answers, we arranged motivational factors from largest to smallest. On average, older employees are motivated by flexibility in the workplace; autonomy at work; good interpersonal relationships in the workplace; the possibility of working at their own pace; respect among employees; equal treatment of employees by age; compliments from the employer for good work; the possibility of working from home; intergenerational cooperation, thereby reducing burdens on the workplace; cooperation with other employees; and the allocation of work by higher salary. On the other hand, younger employees are on average more motivated by higher salary; possibilities of advancement; the possibility for training and education; equal treatment of employees by age; the possibility of autonomy at work; the possibility of working at their own pace; compliments from the employer; respect among employees; good interpersonal relationships in the workplace; flexibility in the workplace; the possibility of diverse work; intergenerational cooperation, thereby reducing the burden on the workplace; the possibility of cooperation with other employees and the allocation of work; and the possibility extended of holidays. The results show that both younger and older employees are satisfied, but the level of satisfaction differs. We sorted satisfaction from the highest to smallest mean values. On average, older employees are more satisfied with interpersonal relationships in the company; their work; working hours and the distribution of work obligations; and facilitation of the self-regulation of the speed of work performed. In the other cases, older employees on average neither agreed nor disagreed with satisfaction with the working conditions, such as better light, air conditioning, and bigger inscriptions; the leadership in the company; flexible working hours and flexible work; intergenerational cooperation and thus distribution of work; the provision of jobsharing, thereby reducing the burden on the workplace; the balance between work and private life; ways of motivating people in the company for better work; or the quantity of programs of active aging and healthy lifestyles. On the other hand, younger employees are on average more satisfied with facilitating self-regulation of the speed of work performed; the working conditions, such as better light, air conditioning, and bigger inscriptions; working hours and distribution of work obligations; their work; and interpersonal relationships in the company. In the other cases, younger employees on average neither agreed or disagreed with satisfaction with the balance between private life and work; the quantity of programs of active aging and healthy lifestyles; flexible working hours; leadership in the company; flexible work; intergenerational cooperation and thus distribution of work; the 
provision of job-sharing, thereby reducing the burden on the workplace; or ways of motivating people in the company for better work. As with older employees, we ranked younger employees' satisfaction, from highest to smallest in the workplace. Motivated and satisfied employees in the workplace are the most complex topic of any modern company. Some important factors have undoubtedly affected employees' level of motivation and satisfaction in the workplace. It is important that the employees feel well at their work and that they are motivated for it or satisfied at work.

Overall, Linz (2004) reported that no major differences were found in the ranking of job motivators of older and younger employees, although older employees placed higher value on pay and security as well as the respect and friendliness of coworkers. According to Claes and Heymans (2008), the motivation of older employees differs from younger employees, as reflected, for example, in the fact that older employees are more motivated by good relationships with employees and employers than younger ones. Older employees are also motivated by the possibility of training, autonomy, and flexibility in the workplace and the possibility of mentoring for newly employed or younger employees. Other studies have also found that, for older employees, monetary incentives are not the primary motivation for the work, while younger employees are motivated by monetary rewards (Noonan, 2005). Various other studies have shown that older employees are more closely connected with internal motivational factors than younger employees. Thus, younger employees are more motivated by external motivation (Kanfer and Ackermann, 2004). Chileshe and Haupt (2010) found that older workers were slightly more satisfied with their jobs than younger ones. Both older and younger workers ranked personal development and quality of life as the two most important job satisfaction factors. Both groups ranked relationship with supervisors and workmates as poor. Chileshe and Haupt (2010) also summarized that age affects the satisfaction derived from work and is directly correlated to motivation. Older workers become less motivated over time. Groot and Brink (1999) found that job satisfaction decreases with hours of work.

The basic condition for successful management of employees in the organization is reflected in the support for high motivation and satisfaction of employees at different ages. Positive changes for age-diverse employees in the workplace will increase work performance. Motivated and satisfacted employees tend to retain a high level of innovation, higher-quality work, and a higher level of efficiency. For older employees, high motivation and satisfaction in the workplace could be essential for dealing with changes in working capabilities and have a significant impact on the well-being of age-diverse employees. Motivation and satisfaction are very important for an organization because they improve the level of efficiency and productivity of age-diverse employees. Motivated and satisfacted employees also build friendly relationships and effectively cooperate with each other. Benefits for the organization are reflected in lower presenteeism, lower absenteeism, lower fluctuation, increased productivity, and higher loyalty of age-diverse employees.

Our study is limited to the field of employees in Slovenia. Another limitation of our research isthe lack of the literature, systematically and comprehensively based on studies and theoretical knowledge about the management of different age groups. For further research we propose the examination of differences in motivation and satisfaction in the workplace between different age groups in various countries. Possibilities for further research also include studies relating to the examination of different measures used in different countries to increase motivation and satisfaction in the workplace among younger and older employees. 


\section{References}

1. Aghazadeh, S. M. (2004), "Managing workforce diversity as an essential resource for improving organizational performance", International Journal of Productivity and Performance Management, Vol. 53, No. 6, pp. 521-531.

2. Artz, B. (2010), "Fringe benefits and job satisfaction", International Journal of Manpower, Vol. 31, No.6, pp. 626-644.

3. Baltes, B.B., Finkelstein, L.M., Kunze, F., Boehm, S.A., Bruch, H. (2011), "Age diversity, age discrimination climate and performance consequences-a cross organizational study", Journal of Organizational Behavior, Vol. 32, No. 2, pp. 264290.

4. Bartol, K. M., Martin, D.C. (1998). Management, McGraw-Hill, New York.

5. Bigliardi, B., Dormio, A.I., Galati, F., Schiuma G. (2012), "The impact of organizational culture on the job satisfaction of knowledge workers", VINE, Vol. 42, No. 1, pp. 36-51.

6. Brooke, L. (2003), "Human resource costs and benefits of maintaining a matureage workforce", International Journal of Manpower, Vol. 24, No. 3, pp. 260-283.

7. Chileshe, N. Haupt, T. C. (2010), "The effect of age on the job satisfaction of construction workers", Journal of Engineering, Design and Technology, Vol. 8, No. 1, pp. 107-118.

8. Claes, R., Heymans, M. (2008), "HR professionals views on work motivation and retention of older workers: a focus group study", Career Development International, Vol. 13, No. 2, pp. 95-111.

9. Garg, P., Rastogi, R. (2006), "New model of job design: motivating employees performance", Journal of Management Development, Vol. 25, No. 6, pp. 572-587.

10. Gellert, F. J., Kuipers, B. S. (2008), "Short- and long-term consequences of age in work teams: An empirical exploration of ageing teams", Career Development International, Vol. 13, No. 2, pp. 132-149.

11. Ghosheh Jr., N. S., Lee, S., McCann, D. (2006). Conditions of work and employment for older workers in industrialized countries: understanding the issues, International Labour Organization, Conditions of Work and Employment Series.

12. Groot, W., Brink, H. M. (1999), "Job satisfaction of older workers", International Journal of Manpower, Vol. 20, No. 6, pp. 343-360.

13. Harrison, D. A., Newman, D. A., Roth, P. L. (2006), "How important are job attitudes? Meta-analytic comparisons of integrative behavioral outcomes and time sequences", Academy of Management Journal, Vol. 49, No. 2, pp. 305-325.

14. Henkens, K., Leenders M. (2010), "Burnout and older workers intentions to retire", International Journal of Manpower, Vol. 31, No. 3, pp. 306-321.

15. Hertel, G., Van der Heijden, B. I. J. M., de Lange, A. H., Deller J. (2013), "Facilitating age diversity in organizations - part 11 : managing perceptions and interactions", Journal of Managerial Psychology, Vol. 28, No. 7/8, pp. 857-866.

16. Ilmarinen, J. (2001), "Aging workers", Occupational and Environmental Medicine, Vol. 58, No. 8, pp. 546-552.

17. Islam, R., Ismail, A. Z. H. (2008), "Employee motivation: a Malaysian perspective", International Journal of Commerce and Management, Vol. 18, No. 4, pp. 344362.

18. Jex, S. M., Britt, T. W. (2008). Organizational Psychology: A Scientist-Practitioner Approach, John Wiley \& Sons, New York.

19. Kanfer, R., Ackerman, P. L. (2004), "Aging, adult development, and work motivation", Academy of Management Review, Vol. 29, No. 3, pp. 440-458.

20. Koc-Menard, S. (2009), "Flexible work options for older workers", Strategic HR Review, Vol. 8, No. 2, pp. 31-36. 
21. Kooij, D., de Lange, A., Jansen, P., Dikkers, J. (2008), "Older workers motivation to continue to work: five meanings of age", Journal of Managerial Psychology, Vol. 23, No. 4, pp. 364-394.

22. Kooij, D., De Lange, A., Jansen, P., Kanfer, R., Dikkers, J. (2011), "Age and workrelated motives: results of a meta-analysis", Journal of Organizational Behavior, Vol. 32, No. 2, pp. 197-225.

23. Lange, A. H., de Taris, T. W., Jansen, P. G. W., Smulders, P., Houtman, I. L. D., Kompier, M. A. J. (2006), "Age as a factor in the relation between work and mental health: results from the longitudinal TAS study", in Houdmont, J., Mclntyre, S. (eds), Occupational Health Psychology: European Perspectives on Research, Education and Practice (Vol. 1), ISMAI Publications, Maia, Portugal, pp. 21-45.

24. Linz, S. J. (2004), "Motivating Russian workers: analysis of gender and age differences", Journal of Socio-Economics, Vol. 33, No. 3, pp. 261-289.

25. Milenovic, Z. M. (2011), "Application of Mann-Whitney $U$ test in research of professional training of primary school teachers", Metodički obzori, Vol. 6, No. 1, pp. 73-79.

26. Monk, R. (1996), "The motivation of managers for training", Management Development Review, Vol. 9, No. 3, pp. 26-32.

27. Moore, F. (2007), "Work-life balance: contrasting managers and workers in an MNC", Employee Relations, Vol. 29, No. 4, pp. 385-399.

28. Noonan, A. E. (2005), "At this point now: Older workers reflections on their current employment experiences", International Journal of Aging and Human Development, Vol. 61, No. 3, pp. 211-241.

29. Origo, F., Pagani, L. (2008), "Workplace flexibility and job satisfaction: some evidence from Europe", International Journal of Manpower, Vol. 29, No. 6, pp. 539-566.

30. Peeters, M.C.W, Emmerik, H. (2008), "An introduction to the work and well-being of older workers: From managing threats to creating opportunities", Journal of Managerial Psychology, Vol. 23, No. 4, pp. 353-363.

31. Rad A. M. M., Yarmohammadian, M. H. (2006), "A study of relationship between managers leadership style and employees job satisfaction", Leadership in Health Services, Vol. 19, No. 2, pp. 11-28.

32. Robson, S. M., Hansson, R. O., Abalos, A., Booth, M. (2006), "Successful aging: criteria for aging well in the workplace", Journal of Career Development, Vol. 33, No. 2, pp. 156-177.

33. Shacklock, K., Brunetto, Y. (2011), "A model of older workers intentions to continue working", Personnel Review, Vol. 40, No. 2, pp. 252-274.

34. Stamov-Roßnagel, C., Biemann, T. (2012), "Ageing and work motivation: a tasklevel perspective", Journal of Managerial Psychology, Vol. 27, No. 5, pp. 459-478.

35. Stamov-Roßnagel, C., Hertel, G. (2010), "Older workers motivation: against the myth of general decline", Management Decision, Vol. 48, No. 6, pp. 894-906.

36. Templer, A., Armstrong-Stassen, M., Cattaneo, J. (2010), "Antecedents of older workers motives for continuing to work", Career Development International, Vol. 15, No. 5, pp. 479-500.

37. UK Essays, (2015), "Employee Motivation in Tourism Industry", available at: https://www.ukessays.com/essays/business/employee-motivation.php (10 april 2016).

38. Van Dick, R., van Knippenberg, D., Hagele, S., Guillaume, Y.R., Brodbeck, F.C. (2008), "Group diversity and group identification: the moderating role of diversity beliefs", Human Relations, Vol. 61, No. 10, pp. 1463-1492. 
39. Wiley, C. (1997) "What motivates employees according to over 40 years of motivation surveys", International Journal of Manpower, Vol. 18, No. 3, pp. 263280.

\section{About the authors}

Maja Rožman, after finishing high school, continued her studies at the Faculty of Economics and Business, University of Maribor, and successfully graduated from Finance and Banking in 2011. In 2013, she acquired her master's degree and is currently earning her PhD at the Faculty of Economics and Business in Maribor at the Department of Management and Organization. She can be contacted at maja.rozman@student.um.si.

Sonja Treven, PhD, is a professor employed at the School of Business and Economics at the University of Maribor in Slovenia in the field of human resource management and organizational behavior. She is the head of the Department of Management and Organisation. She is the author of three books and co-author of more than twenty books as well as more than eighty scientific articles. She has participated in more than 100 domestic and international conferences with her papers as an author or co-author. She can be contacted at sonja.treven@um.si.

Vesna Čančer holds a PhD in Economic and Business Sciences and is an associate professor of quantitative methods in business science at the University of Maribor's Faculty of Economics and Business (UM FEB). Her research focuses primarily on decision analysis, creative problem solving, and research methods, together with their interdisciplinary applications. She is head of the Department of Quantitative Economic Analysis at UM FEB and editor-in-chief of a journal of contemporary issues in economics and business entitled Naše gospodarstvo/Our Economy. She can be contacted at vesna.cancer@um.si. 